Meyrem Arga Şahinoğlu1, Saliha Özelmas Kahya², Esen Çoruh4

Gazi University, marga@gazi.edu.tr, ozelmas@gazi.edu.tr, coruh@gazi.edu.tr, Ankara-Turkey

$$
\text { Derya Çelik }{ }^{3}
$$

Selçuk University, dcelik@selcuk.edu.tr, Ankara-Turkey

http://dx.doi.org/10.12739/NWSA.2016.11.3.3C0144

\title{
FACTORS AFFECTING CLOTHING SELECTIONS OF WORKING WOMEN
}

\begin{abstract}
Turkish women have taken a new role as working women in addition to their role as traditional mother, wife and housewife. At the same time, working women are experts on their field in business life by taking part in highest positions in many areas. In addition, working women follow the fashion more closely and they are defined as the carrier group of fashion as they have economic freedom and they are in interaction with the society. In this research, working women's reasons for buying clothes, clothing perceptions, clothing preparations and factors affecting their clothing selections are tried to be determined. The research's materials are consistent of data and sources obtained from 120 voluntary people selected randomly among the working women in Ankara. As result, it was determined that the women in research consider the colors they want to wear, feeling given by the clothes, events to be participated, weather conditions, work amount in the related day, comfort of the clothes, their psychology in the related day and difference from the previous day when they determine what they will wear in the day.

Keywords: Woman, Working Woman, Clothes, clothing Selection, Psychology
\end{abstract}

\section{ÇALIŞAN KADINLARIN GIYYSI SEÇİMLERINİ ETKİLEYEN ETMENLER}

öz

Türk kadınları geleneksel anne, eş ve ev kadını rollerinin yanı sıra çalışan kadınlar olarak yeni bir rol yüklenmişlerdir. Aynı zamanda, çalışan kadınlar birçok alanda en üst mevkilerde yer alarak çalışma hayatında söz sahibi olmaktadırlar. Ayrıca çalışan kadınlar hem ekonomik özgürlüklerinin olması hem de toplumla etkileşim halinde olası nedeniyle modayı daha yakından takip etmekte ve modanın taşıyıcı grubu olarak tanımlanmaktadırlar. Bu araştırmada; çalışan kadınların giysi satın alma nedenleri, giysiyi algılama durumları, giysilerini hazırlama zamanları, tercihlerini etkileyen etmenler belirlenmeye çalışılmıştır. Araştırmanın materyalini, Ankara ilinde yaşayan, çalışan kadınlar arasından rastlantısal olarak seçilen, araştırmaya katılmaya gönüllü 120 kişiden anket yardımıyla elde edilen veriler ve ilgili kaynaklar oluşturmaktadır. Sonuçta araştırmada çalışan kadınların gün içerisinde giyecekleri giysileri belirlerken sırasıyla; giymek istedikleri renkler, iyi hissetmeleri, katılacakları etkinlikler, havanın durumu, o günkü iş yoğunlukları, giysinin içinde rahat olmaları, o günkü psikolojileri ve bir önceki gün giydikleri giysilerden farklı olmalarına dikkat ettikleri tespit edilmiştir.

Anahtar Kelimeler: Kadın, Çalışan Kadın, Giysi, Giysi Seçim, Psikoloji 


\section{INTRODUCTION}

Today, women comprise half (49.7\%) of the world population. However, women's participation in economic life and level of benefiting from social and economic developments are not directly proportional [1 and 2]. Women are members of a society who are not in the foreground but who have important effects on a society's progress. The more productive and active women in a society the more developed that society will be [3]. Women's effective participation in social and economic development processes and increasing the participation and employment of women in labor force are important factors in realizing sustainable social development [4]. As it is in the world, women's role in society and family changed due to the increase in the population of working women and a new role as working women was attributed to women in addition to traditional roles of mother, spouse and housewife. Assuming new and different roles with these changes and developments in the social structure, women started to receive education, realize their position and become aware. Working women take place at highest positions in many areas and have a voice in working live and governing the country and represent an individual consumer group in areas such as demographic features, lifestyles, attitudes, and media and consumption habits. Needs of women, who gained their financial independence, in clothing as well as in other areas changed when they left behind the identity of "deserving and demanding person" to gain the identity of "earning and deciding person" [5].

Having status determining qualities as well as reflecting personal qualities of a person, clothes are vital necessities which are chosen by women attentively and with the selection of which women mostly feel like they need help. The importance women give to dressing up and aesthetics by their nature causes the variety of colors, shapes and model qualities of their clothes and their choice of clothes to be more comprehensive than men [6].

It is a fact that, in addition to vocational professionalism, clothing also affects a person's career. Various studies revealed that women needed to choose their clothes professionally. For this reason, it is important for a working woman to wear appropriately for her occupational position and the responsibility given to her by the workplace rather than wearing fashionable. For this reason, it should be remembered that there are certain rules about dressing in workplaces. Within the scope of these rules, the wearing alternatives of working women spread into a very wide scale today. On the other hand, serious but also elegant lines are considered appropriate for every kind of workplace [7]. Working women consider their personality, physical structure, age, status, climate conditions, socio-economic status, usage purpose, comfort, compliance with fashion when they choose clothes [8].

Working women of today plan their clothes according to their vocational positions and personal qualities while using these clothes as a means that fulfills the need to dress up and look stylish [9]. Today, the image of working women changed quite a bit and the ideal women started to be defined as "modern, dynamic and working women". Since they have financial independence and they experience joy and taste interactions within the society more intensely, working women always maintained a category that follows fashion more closely compared to housewives and they were defined as the carrier group of fashion [10]. With their more creative, unique and energetic rhythms thanks to the effect of globalization, especially younger working 
generation headed towards to clothes that are easy to wear both in and out of workplaces.

In this research; it is tried to be determined how working women make their choices going to work and what they take into consideration. The material of the research is comprised of data and related resources obtained from 120 working women, chosen among women living in Ankara coincidentally, who are volunteer to participate in the research.

It was determined in the research that working women took into consideration while deciding on the clothes they will wear during a day the colors they wanted to wear on that specific day, the clothes they felt comfortable wearing, the activities they would participate in, weather, work density of that specific day, their psychologies on that day and whether or not they wore the same clothes the day before, respectively.

\section{RESEARCH SIGNIFINANCE}

Women take part in professional life more than in the past. Clothes, which are one of the main needs, are very important tools for women. At the same time, women dressing correctly in the business life may increase their chances of success. The purpose of the research is to reveal working women's reasons for buying clothes, clothing perceptions, clothing preparations and factors affecting their clothing selections. In addition to all of these, it is thought that the research is important in terms of determination of factors affecting daily selection of clothes for increasing their activity in professional life.

\section{METHOD}

In the research, it was used survey method. Data collected by means of a questionnaire and the related resources comprise the material of the research. Sampling of the research is participated in 120 women randomly chosen among women living in Ankara, working in public and private sector.

In this research, a questionnaire was prepared to determine how working women chose their clothes while they go to work and what they took into consideration while making such a choice. The research includes questions to determined why women bought clothes, what clothes meant, the time they determined the clothes they would wear during daytime and the factors they took into consideration while choosing the clothes they would wear during the day.

The data was collected and its frequency and percentage distributions were broken down into cross tables. Furthermore, Cronbach Alpha $(\alpha)$ test statistic results were considered in the research in order to determine the scale reliability for 24 items measured by 4 point Likert scale. If criteria used in the evaluation of Cronbach Alpha Coefficient is $0.70 \leq \alpha<1.00$ the scale is reliable [11]. Cronbach Alpha $(\alpha)$ statistic was also calculated as 0.72 in the research. Reliability of the 24 items used in the questionnaire was proved in reliability test according to these findings. As a result, the questionnaire was a reliable scale.

$x^{2}$ relation analysis was used to measure the statistical relation between the variable of the sector women worked in and the variables of the reasons they bought clothing, what clothes meant for women, the times they determined what to wear during the day and the factors they took into consideration while choosing the clothes to wear during the day. The information regarding the statistical 
relations obtained as a result of $x^{2}$ relation analysis that was made was specified next sections.

\section{FINDINGS AND DISCUSSIONS}

The characteristic findings obtained by means of assessment scale during the research, which was conducted to determine the opinions of working women on how they chose the clothes they wore during the day, about when and according to what criteria women chose the clothes to wear were specified below. It was determined that

- 44.0\% of women participating in the research were in the age group of 30-39 while $41.5 \%$ of them were 40 years old or older and $14.5 \%$ of them were in the age group of 20-29;

- 70.8\% of them had associate or bachelor's degree while 22.5\% of them graduated from high schools and $0.8 \%$ of them graduated from secondary school;

- 57.5\% of them were married while 40.8\% of them were single and $1.7 \%$ of them were divorced.

In the Table 1 , the findings regarding to the reasons why working women bought clothes were presented below;

- The working women of the private sector sometimes (33.3\%) and often (33.3\%) bought "to need clothes", while working women of the public sector always (45.0\%) bought to need clothes.

- The women working both of the sectors often (45.0\%) bought clothes follow up fashion trends.

- 43.3\% of in the private sector showed that they sometimes bought clothes to adopt environment while $48.3 \%$ of them in the public sector found that they sometimes bought clothes for such a reason.

- The working women of the private sector sometimes (61.7\%) and also the working women of the public sector sometimes (50.0\%) bought affordable clothes.

- 38.3\% of the women working in the private sector indicated that they often bought clothes to like a lot while 43.3\% of them found that they always bought them for such a reason.

- The working women both the private sector (46.7\%) and the public sector (50.0\%) often bought clothes to reflect their styles.

- 43.3\% of women working in the private sector sometimes bought clothes to relieve psychologically although $46.7 \%$ of the women working in the public sector always bought clothes to relieve psychologically.

As a result of $x^{2}$ relations analysis that was found a statistically significance such as following up fashion (.000), adapting to the environment (.045) and relieving psychologically $(.008)$.

When Table 2 was examined, the findings of working women opinion related to the meaning of clothing were showed below;

- The working women both the private sector (38.3\%) and the public sector (43.3\%) agree to the statement "Clothing gives the first impression to other people".

- 51.7\% of women working in private sector partly agreed with the statement "Clothing is important for good reputation and prestige" although 45.0\% of the women working in the public sector agreed to that statement.

- The working women of the private sector (53.3\%) and also the public sector (53.3\%) agreed to the statement "Clothing determines a person's status". 
- The women working both the private sector (51.7\%) and the public sector (58.3\%) agreed to the statement "Clothing is important to be chosen in the workplace".

It was determined in the study by koca et al. in 2009 that wearing well was important in earning prestige and good reputation [12]. It is seen in this research that opinions suggesting wearing well made a person earn prestige and good reputation and determined a person's status. The result of the research is in parallel with the study made by Koca et al. As a result of the $x^{2}$ relation analysis that was found a statistically significance related to "clothing is important for good reputation and prestige" (.001).

In the Table 3, the findings regarding to the times of clothing decisions of working women were presented below;

- Both $45.0 \%$ of the women working in private sector and $48.3 \%$ of the women working in the public sector sometimes decided clothing in the evening before.

- 46.7\% of the women working in the private sector often decided it early in the morning although 36.7\% of the women working in the public sector always decided it in the morning.

- The working women both the private sector (60.0\%) and the public sector (86.7\%) sometimes decided what they could find in the morning.

As a result of the $x^{2}$ relation analysis that was found a statistically significance related to "decided what they could find in the morning" (.003).

When Table 4 was examined, the findings of factors affecting clothing selections of working women were showed below;

- The women working both the private sector (46.7\%) and public sector (56.7\%) often preferred wearing clothes in which they feel comfortable.

- 45.0\% of the women working in the private sector stated that they often paid attention to not to wear the clothes they wore the day before while $35.0 \%$ of the women working in the public sector stated that they sometimes paid attention to that.

- Both 53.3\% of the women working in private sector and 50.0\% of the women working in the public sector often decided according to weather.

- 46.7\% of the women working in both the private sector stated that they always decided according to the event they would participate in the meeting etc. while 46.7\% of the women working in the public sector stated that they often decided according to events;

- The working women of the private sector sometimes (45.0\%) and also the working women of the public sector sometimes (61.7\%) decided according to the accessories they wanted to use.

- 51.7\% of the women working in the private sector sometimes selected the clothes they wore the day before while $60.0 \%$ of the women working in the public sector sometimes selected the clothes they wore the day before;

- 58.3\% of the women working in the private sector stated that they always decided according to the color they wanted to wear while $61.7 \%$ of the women working in the public sector stated that they always decided according to the color they wanted to wear;

- Both $41.7 \%$ of the women working in private sector and 46.7\% of the women working in the public sector often wore according to work density on that specific day. 
- 43.3\% of women working in the private sector sometimes decided according to their psychology on that specified day although $58.3 \%$ of the women working in the public sector often decided according to their psychology on that day.

It was determined in a study conducted by Koca and Koç in 2008 that working women paid attention to color harmony while choosing clothes, they felt happy when they wore clothes in harmony, they chose the color of their clothes to cover for their physical defects and based on the thought that clothes earned them prestige rather than bringing their physical appearance to the foreground [6]. It was determined in the study that was conducted that the color working women wanted to wear on that day was one of the most important factors they considered while choosing what to wear on a specific day. It is thought that the fact that working women care so much about the color of the clothes resulted from the reasons specified above. As a result of $x^{2}$ relation analysis conducted, a statistically significant relation was determined between the variable of the sector women are working in and the variable of the factors these women take into consideration while choosing the clothes they will wear during the day such as clothes they feel comfortable wearing (.030), accessories according to which they determined what to wear (.004) and their psychology on that specific day which determined what they wear on that specific day (.000).

\section{CONCLUSION AND RECOMMENDATIONS (SONUÇ VE ÖNERİLER)}

The results obtained during the research conducted to determine working women's opinion about how they determined the clothes they would wear during the day were presented below. It is seen that;

- Working women bought clothes to like a lot, follow up fashion trends, reflected their styles, need, relive psychologically, affordable and adapt to the environment, respectively.

- A big majority of them stated that clothing gave the first impression to other people, provided good reputation and prestige, determined a person's status and were important to be worn in the workplace.

- The highest to lowest number of working women by their time of deciding what to wear was women deciding about it early in the morning, women deciding about it the evening before and women wearing what they could find in the morning.

- The answers given by working women to the questions concentrated on the answers with the color they wanted to wear on that day, the clothes they felt comfortable with, the event they would participate in, the weather, work density on that day, their psychology on that day and paying attention to not to wear the same clothes with the day before, respectively, and the choice with wearing the same clothes with the day before was not preferred.

When results were taken into consideration in general, it can be said that the fact that women determined the clothes they would wear on a specific day beforehand, clothing earned them prestige and good reputation, wearing well was important in determining the social status, clothes preferred to be worn in the workplace were important and they paid attention to and preferred the color they wanted to wear that day and the clothes they wanted to wear that day are all signs of how much importance they gave to clothing. For this reason, it is thought that training to be given by managers in private and public sectors to their employees might make the employees feel happy thus increasing their motivation and productivity at work. 


\section{REFERENCES (KAYNAKLAR)}

1. Pınar, F., (2008). Barbara Frischmuth'ta Çalışan Kadının Sorunları ve Kültürel İlişkiler. Yüksek Lisans Tezi, Yüzüncü Yıl Üniversitesi Sosyal Bilimler Enstitüsü, Van.

2. Demir, G., (1991). Çalışan Kadınlarda Rol Çatışmaları. Doktora Tezi, İnönü Üniversitesi Sosyoloji Ana Bilim Dalı, Malatya.

3. Karabıyık, İ., (2012). Türkiye' de Çalışma Hayatında Kadın İstihdamı. İ.̇ं.B.F. Dergisi, $32(1), 231-260$.

4. Cesim, D., Yücel, A.S., Korkmaz, M., ve Aras, G., (2013). Türkiye'de Kadın İstihdamının Amerika Birleşik Devletlerindeki Kadın İstihdamı İle Karşılaştırılması. Turkish StudiesInternational Periodical For The Languages, Literature and History of Turkish, 8-9, 1845-1863.

5. Skitmore, M. and Ahmad, S., (2000). Work-Family Conflict: A Survey of Singaporean Workers. Singapore Management Review, 251, 35-52.

6. Koca, E. ve Koç, F. (2008). Çalışan Kadınların Giysi Seçimleri ve Renk Tercihleri. Elektronik Sosyal Bilimler Dergisi, 7 (24), 171-200.

7. Üstün, G., (2007). Cumhuriyetten Günümüze Çalışan Kadın Giyimlerinde Moda Faktörü ve Giysi Tercihlerindeki Değişimler. Cumhuriyetin Kadın İmajı Paneli, Hacettepe Üniversitesi, Ankara.

8. Çeğindir, N., (2004). Çalışan Kadınlara Giysi Seçiminde Alternatif Öneriler. Kadın Çalışmalarında Disiplinlerarası Buluşma, Sempozyum Bildiri Metinleri, 1-4 Mart 2004.

9. Üstün, G., (2002). Giyim ve Moda Tarihi. Gazi Üniversitesi Ders Notları, Ankara.

10. Özdemir, H., (2003). Üniversite Öğrencilerinin Giyim Harcamalarında Reklâmların Etkileri. Yüksek Lisans Tezi, Gazi Üniversitesi, Sosyal Bilimler Enstitüsü, İşletme Anabilim Dalı, Ankara.

11. Özdamar, K., (2002). Paket Programlar ile İstatistiksel Veri Analizi. Kaan Kitabevi, Eskişehir.

12. Koca, E., Koç, F., Arga Şahinoğlu, M. ve Pamuk, B., (2009). Toplumsal Statü Açısından Kadının Giysi Tercihlerini Etkileyen Etmenler. Uluslararası Multidisipliner Kadın Kongresi, Dokuz Eylül Üniversitesi, İzmir. 
Arga Şahinoğlu, M., Özelmas Kahya, S., Çelik, D. ve Çoruh, E.

Social Sciences (NWSASOS), 3C0144, 2016; 11(3): 194-204.

Table 1. Working women's reasons for buying clothes

\begin{tabular}{|c|c|c|c|c|c|c|c|c|c|c|c|c|c|c|}
\hline \multirow{3}{*}{ Reasons For Buying Clothes } & \multicolumn{4}{|c|}{ Private Sector } & \multicolumn{4}{|c|}{ Public Sector } & \multicolumn{4}{|c|}{ Total } & \multirow{3}{*}{$x^{2}$} & \multirow{3}{*}{$\mathrm{P}$} \\
\hline & 1 & 2 & 3 & 4 & 1 & 2 & 3 & 4 & 1 & 2 & 3 & 4 & & \\
\hline & $\begin{array}{l}f \\
\%\end{array}$ & $\begin{array}{l}f \\
\frac{o}{0}\end{array}$ & $\begin{array}{l}f \\
\frac{o}{0}\end{array}$ & $\begin{array}{l}f \\
\frac{\circ}{0}\end{array}$ & $\begin{array}{l}f \\
\frac{o}{0}\end{array}$ & $\begin{array}{l}f \\
\frac{o}{0}\end{array}$ & $\begin{array}{l}f \\
\frac{o}{0}\end{array}$ & $\begin{array}{l}f \\
\frac{o}{0}\end{array}$ & $\begin{array}{l}f \\
\frac{o}{0}\end{array}$ & $\begin{array}{l}f \\
\frac{\circ}{0}\end{array}$ & $\begin{array}{l}f \\
\frac{o}{0}\end{array}$ & $\begin{array}{l}f \\
\%\end{array}$ & & \\
\hline To need clothes & $\begin{array}{l}1 \\
1.7\end{array}$ & $\begin{array}{l}20 \\
33.3\end{array}$ & $\begin{array}{l}20 \\
33.3\end{array}$ & $\begin{array}{l}19 \\
31.7\end{array}$ & $\begin{array}{l}2 \\
3.3\end{array}$ & $\begin{array}{l}18 \\
30.0\end{array}$ & $\begin{array}{l}13 \\
21.7\end{array}$ & $\begin{array}{l}27 \\
45.0\end{array}$ & $\begin{array}{l}3 \\
2.5\end{array}$ & $\begin{array}{l}38 \\
31.7\end{array}$ & $\begin{array}{l}33 \\
27.5\end{array}$ & $\begin{array}{l}46 \\
38.3\end{array}$ & 3.315 & .346 \\
\hline To follow up fashion trends & $\begin{array}{l}1 \\
1.7 \\
\end{array}$ & $\begin{array}{l}7 \\
11.7 \\
\end{array}$ & $\begin{array}{l}27 \\
45.0\end{array}$ & $\begin{array}{l}25 \\
41.7\end{array}$ & $\begin{array}{l}0 \\
- \\
\end{array}$ & $\begin{array}{l}26 \\
43.3 \\
\end{array}$ & $\begin{array}{l}27 \\
45.0\end{array}$ & $\begin{array}{l}7 \\
11.7 \\
\end{array}$ & $\begin{array}{l}1 \\
0.8 \\
\end{array}$ & $\begin{array}{l}33 \\
27.5 \\
\end{array}$ & $\begin{array}{l}54 \\
45.0\end{array}$ & $\begin{array}{l}32 \\
26.7\end{array}$ & 22.064 & .000 \\
\hline To adapt to environment & $\begin{array}{l}21 \\
35.0\end{array}$ & $\begin{array}{l}26 \\
43.3\end{array}$ & $\begin{array}{l}9 \\
15.0\end{array}$ & $\begin{array}{l}4 \\
6.7\end{array}$ & $\begin{array}{l}14 \\
23.3\end{array}$ & $\begin{array}{l}29 \\
48.3\end{array}$ & $\begin{array}{l}17 \\
28.3\end{array}$ & $\begin{array}{l}0 \\
.0\end{array}$ & $\begin{array}{l}35 \\
29.2\end{array}$ & $\begin{array}{l}55 \\
45.8\end{array}$ & $\begin{array}{l}26 \\
21.7\end{array}$ & $\begin{array}{l}4 \\
3.3\end{array}$ & 8.025 & .045 \\
\hline To buy affordable clothes & $\begin{array}{l}4 \\
6.7\end{array}$ & $\begin{array}{l}37 \\
61.7\end{array}$ & $\begin{array}{l}10 \\
16.7\end{array}$ & $\begin{array}{l}9 \\
15.0\end{array}$ & $\begin{array}{l}2 \\
3.3\end{array}$ & $\begin{array}{l}30 \\
50.0\end{array}$ & $\begin{array}{l}14 \\
23.3\end{array}$ & $\begin{array}{l}14 \\
23.3\end{array}$ & $\begin{array}{l}6 \\
5.0\end{array}$ & $\begin{array}{l}67 \\
55.8\end{array}$ & $\begin{array}{l}24 \\
20.0\end{array}$ & $\begin{array}{l}23 \\
19.2\end{array}$ & 3.152 & .369 \\
\hline To like clothes a lot & $\begin{array}{l}1 \\
1.7\end{array}$ & $\begin{array}{l}15 \\
25.0\end{array}$ & $\begin{array}{l}23 \\
38.3\end{array}$ & $\begin{array}{l}21 \\
35.0\end{array}$ & $\begin{array}{l}2 \\
3.3\end{array}$ & $\begin{array}{l}8 \\
13.3\end{array}$ & $\begin{array}{l}24 \\
40.0\end{array}$ & $\begin{array}{l}26 \\
43.3\end{array}$ & $\begin{array}{l}3 \\
2.5\end{array}$ & $\begin{array}{l}23 \\
19.2\end{array}$ & $\begin{array}{l}47 \\
39.2\end{array}$ & $\begin{array}{l}47 \\
39.2\end{array}$ & 3.017 & .389 \\
\hline To reflect their styles & $\begin{array}{l}2 \\
3.3\end{array}$ & $\begin{array}{l}15 \\
25.0\end{array}$ & $\begin{array}{l}28 \\
46.7\end{array}$ & $\begin{array}{l}15 \\
25.0\end{array}$ & $\begin{array}{l}9 \\
15.0\end{array}$ & $\begin{array}{l}8 \\
13.3\end{array}$ & $\begin{array}{l}30 \\
50.0\end{array}$ & $\begin{array}{l}13 \\
21.7\end{array}$ & $\begin{array}{l}11 \\
9.2\end{array}$ & $\begin{array}{l}23 \\
19.2\end{array}$ & $\begin{array}{l}58 \\
48.3\end{array}$ & $\begin{array}{l}28 \\
23.3\end{array}$ & 6.797 & .079 \\
\hline To relieve psychologically & $\begin{array}{l}5 \\
8.3\end{array}$ & $\begin{array}{l}26 \\
43.3\end{array}$ & $\begin{array}{l}18 \\
30.0\end{array}$ & $\begin{array}{l}11 \\
18.3\end{array}$ & $\begin{array}{l}5 \\
8.3\end{array}$ & $\begin{array}{l}18 \\
30.0\end{array}$ & $\begin{array}{l}9 \\
15.0\end{array}$ & $\begin{array}{l}28 \\
46.7\end{array}$ & $\begin{array}{l}10 \\
8.3\end{array}$ & $\begin{array}{l}44 \\
36.7\end{array}$ & $\begin{array}{l}27 \\
22.5\end{array}$ & $\begin{array}{l}39 \\
32.5\end{array}$ & 11.865 & .008 \\
\hline
\end{tabular}


Arga Şahinoğlu, M., Özelmas Kahya, S., Çelik, D. ve Çoruh, E. Social Sciences (NWSASOS), 3C0144, 2016; 11(3): 194-204.

Table 2. Working women's clothing perceptions

\begin{tabular}{|c|c|c|c|c|c|c|c|c|c|c|c|c|c|c|}
\hline \multirow{4}{*}{ Clothing Perceptions } & \multicolumn{4}{|c|}{ Private Sector } & \multicolumn{4}{|c|}{ Public Sector } & \multicolumn{4}{|c|}{ Total } & \multirow{4}{*}{$x^{2}$} & \multirow{4}{*}{$\mathrm{P}$} \\
\hline & 1 & 2 & 3 & 4 & 1 & 2 & 3 & 4 & 1 & 2 & 3 & 4 & & \\
\hline & $\mathrm{f}$ & f & $\mathrm{f}$ & f & f & $f$ & f & f & f & $f$ & f & $\mathrm{f}$ & & \\
\hline & $\frac{\circ}{0}$ & $\frac{\circ}{0}$ & $\frac{\circ}{0}$ & $\%$ & $\div$ & $\frac{\circ}{0}$ & $\%$ & $\div$ & $\%$ & $\div$ & $\div$ & $\%$ & & \\
\hline $\begin{array}{l}\text { Clothing gives the first } \\
\text { impression to other people }\end{array}$ & $\begin{array}{l}4 \\
6.7\end{array}$ & $\begin{array}{l}18 \\
30.0\end{array}$ & $\begin{array}{l}23 \\
38.3\end{array}$ & $\begin{array}{l}15 \\
25.0\end{array}$ & $\begin{array}{l}6 \\
10.0\end{array}$ & $\begin{array}{l}10 \\
16.7\end{array}$ & $\begin{array}{l}26 \\
43.3\end{array}$ & $\begin{array}{l}18 \\
30.0\end{array}$ & $\begin{array}{l}10 \\
8.3\end{array}$ & $\begin{array}{l}28 \\
23.3\end{array}$ & $\begin{array}{l}49 \\
40.8\end{array}$ & $\begin{array}{l}33 \\
27.5\end{array}$ & 3.142 & .370 \\
\hline $\begin{array}{l}\text { Clothing is important for } \\
\text { good reputation and prestige }\end{array}$ & $\begin{array}{l}1 \\
1.7\end{array}$ & $\begin{array}{l}31 \\
51.7\end{array}$ & $\begin{array}{l}20 \\
33.3\end{array}$ & $\begin{array}{l}8 \\
13.3\end{array}$ & $\begin{array}{l}9 \\
15.0\end{array}$ & $\begin{array}{l}12 \\
20.0\end{array}$ & $\begin{array}{l}27 \\
45.0\end{array}$ & $\begin{array}{l}12 \\
20.0\end{array}$ & $\begin{array}{l}10 \\
8.3\end{array}$ & $\begin{array}{l}43 \\
35.8\end{array}$ & $\begin{array}{l}47 \\
39.2\end{array}$ & $\begin{array}{l}20 \\
16.7\end{array}$ & 16.638 & .001 \\
\hline $\begin{array}{l}\text { Clothing determines a } \\
\text { person's status }\end{array}$ & $\begin{array}{l}8 \\
13.3\end{array}$ & $\begin{array}{l}12 \\
20.0\end{array}$ & $\begin{array}{l}32 \\
53.3\end{array}$ & $\begin{array}{l}8 \\
13.3\end{array}$ & $\begin{array}{l}1 \\
1.7\end{array}$ & $\begin{array}{l}12 \\
20.0\end{array}$ & $\begin{array}{l}32 \\
53.3\end{array}$ & $\begin{array}{l}15 \\
25.0\end{array}$ & $\begin{array}{l}9 \\
7.5\end{array}$ & $\begin{array}{l}24 \\
20.0\end{array}$ & $\begin{array}{l}64 \\
53.3\end{array}$ & $\begin{array}{l}23 \\
19.2\end{array}$ & 7.575 & .056 \\
\hline $\begin{array}{l}\text { Clothing is important to be } \\
\text { chosen in the workplace }\end{array}$ & $\begin{array}{l}7 \\
11.7\end{array}$ & $\begin{array}{l}11 \\
18.3\end{array}$ & $\begin{array}{l}31 \\
51.7\end{array}$ & $\begin{array}{l}11 \\
18.3\end{array}$ & $\begin{array}{l}2 \\
3.3\end{array}$ & $\begin{array}{l}8 \\
13.3\end{array}$ & $\begin{array}{l}35 \\
58.3\end{array}$ & $\begin{array}{l}15 \\
25.0\end{array}$ & $\begin{array}{l}9 \\
7.5\end{array}$ & $\begin{array}{l}19 \\
15.8\end{array}$ & $\begin{array}{l}66 \\
55.0\end{array}$ & $\begin{array}{l}26 \\
21.7\end{array}$ & 4.109 & .250 \\
\hline
\end{tabular}

$\mathrm{n}=120$ (1.I do not agree, 2.I agree partly, 3.I agree, 4.I agree completely) $\mathrm{P}<0.05$ 
Arga Şahinoğlu, M., Özelmas Kahya, S., Çelik, D. ve Çoruh, E. Social Sciences (NWSASOS), 3C0144, 2016; 11(3): 194-204.

Table 3. Working women's clothing preparations

\begin{tabular}{|c|c|c|c|c|c|c|c|c|c|c|c|c|c|c|}
\hline \multirow{4}{*}{ Clothing Preparations } & \multicolumn{4}{|c|}{ Private Sector } & \multicolumn{4}{|c|}{ Public Sector } & \multicolumn{4}{|c|}{ Total } & \multirow{4}{*}{$x^{2}$} & \multirow{4}{*}{$\mathrm{P}$} \\
\hline & 1 & 2 & 3 & 4 & 1 & 2 & 3 & 4 & 1 & 2 & 3 & 4 & & \\
\hline & f & f & f & f & f & f & f & f & $f$ & f & f & f & & \\
\hline & $\%$ & $\div$ & $\frac{0}{0}$ & $\%$ & $\frac{\circ}{0}$ & $\frac{\circ}{0}$ & $\%$ & $\%$ & $\frac{\circ}{0}$ & $\frac{\circ}{0}$ & $\%$ & $\%$ & & \\
\hline $\begin{array}{l}\text { I decide it in the evening } \\
\text { before }\end{array}$ & $\begin{array}{l}7 \\
11.7\end{array}$ & $\begin{array}{l}27 \\
45.0\end{array}$ & $\begin{array}{l}19 \\
31.7\end{array}$ & $\begin{array}{l}7 \\
11.7\end{array}$ & $\begin{array}{l}10 \\
16.7\end{array}$ & $\begin{array}{l}29 \\
48.3\end{array}$ & $\begin{array}{l}21 \\
35.0\end{array}$ & $\begin{array}{l}0 \\
-\end{array}$ & $\begin{array}{l}17 \\
14.2\end{array}$ & $\begin{array}{l}56 \\
46.7\end{array}$ & $\begin{array}{l}40 \\
33.3\end{array}$ & $\begin{array}{l}7 \\
5.8\end{array}$ & 7.701 & .053 \\
\hline $\begin{array}{l}\text { I decide it early in the } \\
\text { morning }\end{array}$ & $\begin{array}{l}1 \\
1.7 \\
\end{array}$ & $\begin{array}{l}14 \\
23.3\end{array}$ & $\begin{array}{l}28 \\
46.7\end{array}$ & $\begin{array}{l}17 \\
28.3\end{array}$ & $\begin{array}{l}2 \\
3.3 \\
\end{array}$ & $\begin{array}{l}15 \\
25.0\end{array}$ & $\begin{array}{l}21 \\
35.0\end{array}$ & $\begin{array}{l}22 \\
36.7 \\
\end{array}$ & $\begin{array}{l}3 \\
2.5 \\
\end{array}$ & $\begin{array}{l}29 \\
24.2 \\
\end{array}$ & $\begin{array}{l}49 \\
40.8\end{array}$ & $\begin{array}{l}39 \\
32.5\end{array}$ & 2.009 & .571 \\
\hline $\begin{array}{l}\text { I decide what I can find in } \\
\text { the morning }\end{array}$ & $\begin{array}{l}23 \\
38.3 \\
\end{array}$ & $\begin{array}{l}36 \\
60.0 \\
\end{array}$ & $\begin{array}{l}1 \\
1.7 \\
\end{array}$ & $\begin{array}{ll}0 \\
- \\
\end{array}$ & $\begin{array}{l}7 \\
11.7 \\
\end{array}$ & $\begin{array}{l}52 \\
86.7\end{array}$ & $\begin{array}{l}1 \\
1.7 \\
\end{array}$ & $\begin{array}{l}0 \\
- \\
\end{array}$ & $\begin{array}{l}30 \\
25.0\end{array}$ & $\begin{array}{l}88 \\
73.3 \\
\end{array}$ & $\begin{array}{l}2 \\
1.7 \\
\end{array}$ & $\begin{array}{l}0 \\
- \\
\end{array}$ & 11.442 & .003 \\
\hline
\end{tabular}


Arga Şahinoğlu, M., Özelmas Kahya, S., Çelik, D. ve Çoruh, E. Social Sciences (NWSASOS), 3C0144, 2016; 11(3): 194-204.

Table 4. Factors affecting clothing selections of working women

\begin{tabular}{|c|c|c|c|c|c|c|c|c|c|c|c|c|c|c|}
\hline \multirow{3}{*}{$\begin{array}{l}\text { Affecting Factors of Clothing } \\
\text { Selections }\end{array}$} & \multicolumn{4}{|c|}{ Private Sector } & \multicolumn{4}{|c|}{ Public Sector } & \multicolumn{4}{|c|}{ Total } & \multirow{3}{*}{$x^{2}$} & \multirow{3}{*}{$\mathrm{P}$} \\
\hline & 1 & 2 & 3 & 4 & 1 & 2 & 3 & 4 & 1 & 2 & 3 & 4 & & \\
\hline & $\begin{array}{l}f \\
\frac{\circ}{0}\end{array}$ & $\begin{array}{l}f \\
\%\end{array}$ & $\begin{array}{l}f \\
\frac{\circ}{0}\end{array}$ & $\begin{array}{l}f \\
\%\end{array}$ & $\begin{array}{l}f \\
\%\end{array}$ & $\begin{array}{l}f \\
\%\end{array}$ & $\begin{array}{l}f \\
\frac{\circ}{0}\end{array}$ & $\begin{array}{l}f \\
\%\end{array}$ & $\begin{array}{l}f \\
\frac{\circ}{0}\end{array}$ & $\begin{array}{l}f \\
\frac{o}{0}\end{array}$ & $\begin{array}{l}f \\
\frac{\circ}{0}\end{array}$ & $\begin{array}{l}f \\
\frac{\circ}{0}\end{array}$ & & \\
\hline $\begin{array}{l}\text { I prefer wearing clothes in which } \\
\text { I feel comfortable }\end{array}$ & $\begin{array}{ll}0 \\
-\end{array}$ & $\begin{array}{l}11 \\
18.3\end{array}$ & $\begin{array}{l}28 \\
46.7\end{array}$ & $\begin{array}{l}21 \\
35.0\end{array}$ & $\begin{array}{l}0 \\
-\end{array}$ & $\begin{array}{l}2 \\
3.3\end{array}$ & $\begin{array}{l}34 \\
56.7\end{array}$ & $\begin{array}{l}24 \\
40.0\end{array}$ & $\begin{array}{l}0 \\
-\end{array}$ & $\begin{array}{l}13 \\
10.8\end{array}$ & $\begin{array}{l}62 \\
51.7\end{array}$ & $\begin{array}{l}45 \\
37.5\end{array}$ & 7.011 & .030 \\
\hline $\begin{array}{l}\text { I pay attention to not to wear } \\
\text { the clothes I wore the day before }\end{array}$ & $\begin{array}{l}2 \\
3.3\end{array}$ & $\begin{array}{l}18 \\
30.0\end{array}$ & $\begin{array}{l}27 \\
45.0\end{array}$ & $\begin{array}{l}13 \\
21.7\end{array}$ & $\begin{array}{l}4 \\
6.7\end{array}$ & $\begin{array}{l}21 \\
35.0\end{array}$ & $\begin{array}{l}18 \\
30.0\end{array}$ & $\begin{array}{l}17 \\
28.3\end{array}$ & $\begin{array}{l}6 \\
5.0\end{array}$ & $\begin{array}{l}39 \\
32.5\end{array}$ & $\begin{array}{l}45 \\
37.5\end{array}$ & $\begin{array}{l}30 \\
25.0\end{array}$ & 3.231 & .357 \\
\hline I decide according to weather & $\begin{array}{l}1 \\
1.7\end{array}$ & $\begin{array}{l}10 \\
16.7\end{array}$ & $\begin{array}{l}32 \\
53.3\end{array}$ & $\begin{array}{l}17 \\
28.3\end{array}$ & $\begin{array}{l}0 \\
-\end{array}$ & $\begin{array}{l}6 \\
10.0\end{array}$ & $\begin{array}{l}30 \\
50.0\end{array}$ & $\begin{array}{l}24 \\
40.0\end{array}$ & $\begin{array}{l}1 \\
0.8\end{array}$ & $\begin{array}{l}16 \\
13.3\end{array}$ & $\begin{array}{l}62 \\
51.7\end{array}$ & $\begin{array}{l}41 \\
34.2\end{array}$ & 3.260 & .353 \\
\hline $\begin{array}{l}\text { I decide according to the event I } \\
\text { will participate in meetings etc. }\end{array}$ & $\begin{array}{l}1 \\
1.7\end{array}$ & $\begin{array}{l}5 \\
8.3\end{array}$ & $\begin{array}{l}26 \\
43.3\end{array}$ & $\begin{array}{l}28 \\
46.7\end{array}$ & $\begin{array}{l}0 \\
-\end{array}$ & $\begin{array}{l}8 \\
13.3\end{array}$ & $\begin{array}{l}28 \\
46.7\end{array}$ & $\begin{array}{l}24 \\
40.0\end{array}$ & $\begin{array}{l}1 \\
0.8\end{array}$ & $\begin{array}{l}13 \\
10.8\end{array}$ & $\begin{array}{l}54 \\
45.0\end{array}$ & $\begin{array}{l}52 \\
43.3\end{array}$ & 2.074 & .557 \\
\hline $\begin{array}{l}\text { I decide according to the } \\
\text { accessory I want to use }\end{array}$ & $\begin{array}{l}17 \\
28.3\end{array}$ & $\begin{array}{l}27 \\
45.0\end{array}$ & $\begin{array}{l}6 \\
10.0\end{array}$ & $\begin{array}{l}10 \\
16.7\end{array}$ & $\begin{array}{l}4 \\
6.7\end{array}$ & $\begin{array}{l}37 \\
61.7\end{array}$ & $\begin{array}{l}2 \\
3.3\end{array}$ & $\begin{array}{l}17 \\
28.3\end{array}$ & $\begin{array}{l}21 \\
17.5\end{array}$ & $\begin{array}{l}64 \\
53.3\end{array}$ & $\begin{array}{l}8 \\
6.7\end{array}$ & $\begin{array}{l}27 \\
22.5\end{array}$ & 13.425 & .004 \\
\hline $\begin{array}{l}\text { I prefer wearing the clothes I } \\
\text { wore the day before }\end{array}$ & $\begin{array}{l}28 \\
46.7\end{array}$ & $\begin{array}{l}31 \\
51.7\end{array}$ & $\begin{array}{l}1 \\
1.7\end{array}$ & $\begin{array}{l}0 \\
-\end{array}$ & $\begin{array}{l}24 \\
40.0\end{array}$ & $\begin{array}{l}36 \\
60.0\end{array}$ & $\begin{array}{l}0 \\
-\end{array}$ & $\begin{array}{l}0 \\
-\end{array}$ & $\begin{array}{l}52 \\
43.3\end{array}$ & $\begin{array}{l}67 \\
55.8\end{array}$ & $\begin{array}{l}1 \\
0.8\end{array}$ & $\begin{array}{l}0 \\
-\end{array}$ & 1.681 & .432 \\
\hline $\begin{array}{l}\text { I decide according to the color I } \\
\text { want to wear that day }\end{array}$ & $\begin{array}{l}1 \\
1.7\end{array}$ & $\begin{array}{l}9 \\
15.0\end{array}$ & $\begin{array}{l}15 \\
25.0\end{array}$ & $\begin{array}{l}35 \\
58.3\end{array}$ & $\begin{array}{l}0 \\
-\end{array}$ & $\begin{array}{l}2 \\
3.3\end{array}$ & $\begin{array}{l}21 \\
35.0\end{array}$ & $\begin{array}{l}37 \\
61.7\end{array}$ & 1 & $\begin{array}{l}11 \\
9.2\end{array}$ & $\begin{array}{l}36 \\
30.0\end{array}$ & $\begin{array}{l}72 \\
60.0\end{array}$ & 6.510 & .089 \\
\hline $\begin{array}{l}\text { I decide according to my work } \\
\text { density on that specific day }\end{array}$ & $\begin{array}{l}1 \\
1.7\end{array}$ & $\begin{array}{l}19 \\
31.7\end{array}$ & $\begin{array}{l}25 \\
41.7\end{array}$ & $\begin{array}{l}15 \\
25.0\end{array}$ & $\begin{array}{l}2 \\
3.3\end{array}$ & $\begin{array}{l}10 \\
16.7\end{array}$ & $\begin{array}{l}28 \\
46.7\end{array}$ & $\begin{array}{l}20 \\
33.3\end{array}$ & $\begin{array}{l}3 \\
2.5\end{array}$ & $\begin{array}{l}29 \\
24.2\end{array}$ & $\begin{array}{l}53 \\
44.2\end{array}$ & $\begin{array}{l}35 \\
29.2\end{array}$ & 4.011 & .260 \\
\hline $\begin{array}{l}\text { I decide according to my } \\
\text { psychology on that day }\end{array}$ & $\begin{array}{l}4 \\
6.7\end{array}$ & $\begin{array}{l}26 \\
43.3\end{array}$ & $\begin{array}{l}22 \\
36.7\end{array}$ & $\begin{array}{l}8 \\
13.3\end{array}$ & $\begin{array}{l}0 \\
-\end{array}$ & $\begin{array}{l}8 \\
13.3\end{array}$ & $\begin{array}{l}35 \\
58.3\end{array}$ & $\begin{array}{l}17 \\
28.3\end{array}$ & $\begin{array}{l}4 \\
3.3\end{array}$ & $\begin{array}{l}34 \\
28.3\end{array}$ & $\begin{array}{l}57 \\
47.5\end{array}$ & $\begin{array}{l}25 \\
20.8\end{array}$ & 19.734 & .000 \\
\hline
\end{tabular}

$\mathrm{n}=120$ (1. Never, 2. Sometimes, 3. Often, 4. Always) $\mathrm{P}<0.05$ 